\title{
Can Plant Microbiome Studies Lead to Effective Biocontrol of Plant Diseases?
}

\author{
Jeffrey G. Ellis \\ CSIRO Agriculture and Food, Canberra, Australia
}

Accepted 5 December 2016.

In this review, the wisdom and efficacy of studies seeking disease attenuating microbes and microbiomes only in healthy plant communities is questioned and an alternative view is posited, namely that success in biocontrol of crop diseases may also come from studies of microbiota, or at least individual species isolates, associated with diseased plants. In support of this view, I summarize the current extensive knowledge of the biology behind what is probably the most successful biocontrol of a plant disease, namely the biocontrol of crown gall of stone fruit using nonpathogenic Rhizobium rhizogenes $\mathrm{K84}$, in which the biocontrol agent itself came from a diseased plant.

Description of plant microbiomes by DNA sequencing, extensive bioinformatic analysis, and the establishment of large culture collections of the microbial components is a rapidly expanding new area in plant biology. This is seen to have applications in new approaches to minimize plant disease (Bulgarelli et al. 2013; Poudel et al. 2016; Raaijmakers and Mazzola 2016; Servick 2016). The theory is that the microbiome of healthy plants protects them from pathogen infection and that establishing and encouraging a 'healthy microbiome' through application of a complex consortia of microbes to seed, cuttings, and tubers or directly to soils and growing crops will lead to improved yield and wealth-generating disease control technologies. This philosophy partly derives from studies over many years of 'disease suppressive soils,' in which it is thought that soil microbiota suppress crop diseases even in the presence of pathogens (Raaijmakers and Mazzola 2016).

In this commentary, I question the wisdom and efficacy of studies seeking disease attenuating microbes and microbiomes only in healthy plant communities and posit the alternative view that success in biocontrol of crop diseases may also come from studies of microbiota or, at least, individual species isolates associated with diseased plants. In support of this view, I summarize the current extensive knowledge of the biology behind what is probably the most successful biocontrol of a plant disease, namely the biocontrol of crown gall of stone fruit, using nonpathogenic Rhizobium rhizogenes K84 (Kerr 2016; New and

This paper is dedicated to Allen Kerr and Max Tate who discovered K84 and agrocin 84 and to Stephen Farrand who uncovered much of the molecular genetics of K84.

Corresponding author: E-mail: Jeff.ellis@csiro.au

This article is in the public domain and not copyrightable. It may be freely reprinted with customary crediting of the source. The American Phytopathological Society, 2017.
Kerr 1972), in which the biocontrol agent itself came from a diseased plant. I argue that the success of this organism as a biocontrol agent stems from its evolution as a "cheater" (Rose 1978) or microbial cuckoo, an active exploiter of the diseased plant niche at the expense of the disease-inducing pathogen. Cheater attributes of K84 are the result of natural selection for abilities to outcompete the disease-inducing pathogen (but not eliminate the disease!) using at least two pathogen-specific antibiotics and specialized functions for inhabiting the crown gall environment.

Much of the biology underlying the cheater attributes of K84 have been uncovered by extensive molecular-genetic, biological, and chemical studies (Kerr and Htay 1974; Kim et al. 2006; Reader et al. 2005; Tate et al. 1979). Biocontrol of crown gall has resulted from two human interventions disrupting the normal lifestyle of K84: first, introduction of a high population level of K84 into the infection court prior to pathogen infection and, second, genetic engineering of the K84 to enhance durability of disease control (Jones and Kerr 1989). The questions are whether other such cheater organisms isolated from plants with diverse diseases can be turned against pathogens more generally and whether such organisms can be identified by studying microbiomes of the diseased plant niche.

\section{Terms and definitions.}

Some technical terms are defined for readers who are not familiar with crown gall biology.

Ti plasmid, T region, T-DNA, virulence genes, opines. The genes for crown gall tumor formation in Agrobacterium and Rhizobium species are carried on large plasmids called tumor inducing (Ti) plasmids. The $\mathrm{T}$ region of the Ti plasmid contains a set of genes that are transferred to plant cells. The $\mathrm{T}$ region DNA is processed in bacteria and is transferred to plant cells using products of a set of Ti plasmid genes called virulence genes. The processed $\mathrm{T}$ region integrates into the host genome and is called transferred- or T-DNA. Among several products of T-DNA genes expressed in crown gall tumors are enzymes that lead to the synthesis of novel small-molecular weight products, opines, that are used as specific food sources for bacterial species that carry genes for opine catabolism, either on the Ti plasmid or related plasmids that do not carry the $\mathrm{T}$ region and virulence genes. Certain opine groups also induce the transfer of $\mathrm{Ti}$ and related plasmids from plasmid donors to recipients during the process of bacterial conjugation.

Infection court. The place in or on the susceptible plant where infection may be initiated by a pathogen.

Current Agrobacterium taxonomy. The designation of the crown gall-inducing and related nonpathogenic bacteria mostly covered in this summary (New and Kerr 1971) are now referred to as Rhizobium rhizogenes, while the species that was studied 
most widely in uncovering the molecular basis of crown gall induction and developing plant transformation biotechnology (formerly Agrobacterium tumefaciens) is referred to as Rhizobium radiobacter (Young et al. 2001).

\section{The search for biocontrol agents.}

Attempts to use biological control for various plant diseases have involved introduction of microbes (viruses, bacteria, or fungi) into infection courts of plant pathogens, with the aim of achieving economic control of diseases. After more than 40 years (Baker and Cook 1974), this continues to be a very active area of research with an increasing number of biotech companies now being involved, perhaps spurred on by the development of inexpensive and rapid microbiome DNA sequencing, and the view that this new information of plant-associated microbes will provide more effective routes for identification of new biocontrol agents. The aim is to discover commercial treatments for crop disease problems that can be marketed without exposure to the enormous scientific challenges and regulatory costs of developing disease resistant genetically modified crops.

However, when searching for currently successful biocontrol achievements in the field, I note very few. There are examples of some level of control of disease in some places and in some years and positive effects from using biocontrol as part of an 'integrated disease management' package or in glasshouse crops. But I am setting the bar for success extremely high, having had association with the 'gold standard' example, the biocontrol of crown gall in stone fruit orchards based on the control agent Rhizobium rhizogenes $\mathrm{K} 84$, which has practically driven this disease to extinction in Australia (Kerr 2016). What lessons can we derive from understanding the biology behind the success of crown gall control that may lead to the discovery of more effective biocontrol of other diseases?

\section{The biology of biocontrol of crown gall disease using $\mathrm{K84}$.}

Background information for crown gall disease and its biological control. Crown gall on stone fruit (including almonds) in South Australia and many other parts of the world is caused by Rhizobium rhizogenes. This pathogen induces crown gall tumors that synthesize two opines, nopaline (Goldmann et al. 1969) and agrocinopine A (Ellis and Murphy 1981; Ryder et al. 1984), as a result of transfer and expression of T-DNA genes into plant cells. These pathogens catabolize nopaline and agrocinopine A as carbon, nitrogen, and phosphorus sources for growth and so essentially 'farm' the plant for a nutrient supply. Furthermore, agrocinopine A plays an additional role in pathogen biology by being the inducer of conjugal transfer of the Ti plasmid between pathogenic agrobacteria and nonpathogens in the crown gall environment (Ellis et al. 1982).

During the isolation of pathogenic strains of Rhizobium rhizogenes from South Australian orchards (and elsewhere) with crown gall, nonpathogenic strains of the same species were also isolated (New and Kerr 1972). These strains fall into two classes (Kerr and Roberts 1976). The first are unable to catabolize nopaline and agrocinopine A and will not be discussed further here. The second, although nonpathogenic, can also catabolize these opines. Both these classes of organisms can be considered 'freeloaders' on the disease niche created by the pathogen. The nonpathogenic $\mathrm{K} 84$ is in the second class and was isolated from a peach crown gall and has been used extensively across the world as a highly successful biocontrol agent of crown gall in stone fruit. It, as outlined below, is one step away from a simple freeloader and is a sophisticated cheater carrying the biological means to outcompete the pathogen in the disease niche. For biocontrol of crown gall, susceptible but uninfected planting material (seed and grafted seedlings) are dipped in a cell suspension of $\mathrm{K} 84$ at the time of planting, from which moment
K84 acts as a highly effective prophylactic protecting the plant from crown gall. However K84 cannot 'cure' preformed crown gall.

The molecular biology of strain K84 and 'Trojan horse' antibiotics. The biocontrol ability of K84 depends on its production of anti-Rhizobium rhizogenes antibiotics. The major biocontrol chemical is agrocin 84 , a di-substituted adenine nucleotide (Tate et al. 1979). Synthesis of agrocin 84 is encoded by the 44-kb plasmid pAg84a and experimental transfer of this plasmid to a nonpathogenic and nonantibiotic-producing recipient strain is sufficient to convert this strain to an agrocin 84 producer and effective biocontrol in glasshouse tests in tomato plants (Ellis et al. 1979). K84 produces a second antibiotic, agrocin 434, a di-substituted cytidine nucleoside encoded by the plasmid pAgK434 (>300 kb) (Donner et al. 1993). Agrocin 434 also plays a role in biocontrol of crown gall (McClure et al. 1998). Most pathogens carrying the nopaline/agrocinopine Ti plasmid are sensitive to agrocin 84 and all Rhizobium rhizogenes (except producers of agrocin 434) are sensitive to agrocin 434. The third antimicrobial is ALS84, which is toxic to several species of bacteria under low-iron concentrations, is likely to be identical to a siderophore produced by this strain (Penyalver et al. 2001). The role of this siderophore in biocontrol has not been explored but may enhance the general competitive ability of K84 against other microbial species in the rhizosphere and crown gall niche when iron is limiting.

The mode of action of agrocin 84 has been studied extensively. Agrocin 84 is the foundation member of a class of antibiotics specifically inhibiting a very narrow range of bacterial targets and were first referred to by Tate et al. (1979) as Trojan horse antibiotics. This class of antibiotics is functionally defined as those that use a range of secondary substituents to efficiently internalize an otherwise membrane-excluded toxic moiety into target cells by virtue of pores and permeases in bacterial membranes. In the case of agrocin 84 its $\mathrm{N}_{6}$-D-glucofuranosyloxyphosphoramidate substituent 'tricks' a high-efficiency transport system for its uptake into target cells. This substituent mimics the region of agrocinopine A, arabinose-2-phosphate, responsible for its specific interaction with a $\mathrm{Ti}$ plasmid-encoded periplasmic binding protein, AccA, the first component of an $\mathrm{ABC}$ transporterbased agrocinopine A permease (El Sahili et al. 2015). Interestingly agrocin 84 itself is not toxic until processed inside the target cell by the AccF enzyme, a phosphodiesterase involved in degradation of agrocinopine A (Kim and Farrand 1997). The toxic product of agrocin 84 , called agrocin 84 toxic moiety (agrocin 84TM) (Reader et al. 2005), inhibits leucyltRNA synthetase involved in the attachment of leucine to tRNA, resulting in the blockage of protein synthesis (Reader et al. 2005). The narrow range of specificity of the second antibiotic, agrocin 434 (Rhizobium rhizogenes), is also consistent with a Trojan horse function, although its full chemical structure and mode of action are unknown. Several other narrow specificity Trojan horse antibiotics that involve a toxic component and a second component for high-efficiency delivery into target cells have now been identified in other bacterial species and have been investigated to develop synthetic, narrow-spectrum, high-activity antibiotics for human medicine (Grinter et al. 2013; Rebuffat 2012).

Immunity of strain K84 to agrocin 84. Antibiotic-producing organisms like K84 have systems to avoid effects of their own toxic products (Ryder et al. 1987). Three independent immunity systems act in K84. First, the agrocin 84 plasmid pAgK84a encodes a leucyl-tRNA synthetase resistant to inhibition by agrocin 84TM (Reader et al. 2005). The second component is a highly efficient pump that transports agrocin 84 out of the producer cell (Kim et al. 2006). The third is modified agrocinopine A catabolism by K84 compared with that in pathogens. Pathogens 
that have acquired the agrocin 84 plasmid via conjugation from K84 do not produce agrocin 84 when induced by agrocinopine A (as they are in the crown gall tumor where agrocinopine $A$ is synthesized) or when they are constitutive for its catabolism due to expression of Ti plasmid-encoded proteins, probably AccF, which removes the $\mathrm{N}_{6}$-D-glucofuranosyloxyphosphoramidate substituent (Ellis et al. 1982; Kim et al. 2006; Ryder et al. 1987). However in contrast to the Ti plasmid-encoded pathway, agrocinopine A catabolic enzymes in K84, encoded on the large catabolic plasmid pAg84b, do not inactivate agrocin 84 and the agrocinopine permease, and the agrocin permease in this strain does not take up agrocin 84 (Hayman and Farrand 1990). Not breaking down or reimporting secreted agrocin 84 in the crown gall environment makes functional sense for the evolution of K84 as a cheater using agrocin 84 as a weapon.

Strain 84 is a consummate cheater. Being closely related to the pathogen strains (in fact, the same species as strains causing crown gall on stone fruit), K84 is well adapted to life in the rhizosphere and crown gall tumors of stone fruit plants. It uses a suite of antibiotics, principally agrocin 84 , to out-compete pathogens in preformed crown gall tumors. It also carries genes on a large plasmid, pAg84b, needed to use opines nopaline and agrocinopine A, synthesized by crown gall tumors. So in nature, the success of K84 as a cheater depends on it initially being in low numbers compared with pathogen numbers in the rhizosphere so that the pathogens can induce crown galls for K84 to invade and proliferate in.

\section{Conversion of a cheater to a biological control agent.}

In the case of strain $\mathrm{K} 84$, human intervention has converted a cheater into a highly effective biological control agent. In contrast to its usual lifestyle among crown gall tumors, K84 is now introduced at high cell density into uninfected planting material. The very characteristics of the cheater, namely adaptation to the rhizosphere enabling efficient colonization of treated planting material and antibiotic production, function to inhibit pathogen cells when K84 is introduced into the infection court prior to infection of the host by the pathogen.

As part of the management and stewardship of this biological control, steps were taken to avoid its breakdown in the field. Potential for breakdown of biocontrol by strain K84 due to transfer of the plasmid pAg84a-encoding agrocin 84 synthesis and resistance to this antibiotic encoded into pathogens was recognized (Panagopoulos et al. 1978) and defused by developing a derivative of $\mathrm{K} 84$, called $\mathrm{K} 1026$, by deletion of genes required for pAg84 plasmid transfer from K84 to pathogens (Jones et al. 1988). K1026, the first genetically engineered, registered biocontrol agent, has widely replaced K84 for biocontrol applications (Kerr 2016). Further, selection and survival of pathogen mutants in Rhizobium rhizogenes resistant to agrocin 84 is unlikely, because these retain sensitivity to agrocin 434 that is coexpressed with agrocin 84 . Alternatively, transfer of the Ti plasmid from the pathogen to strain $\mathrm{K} 84$, converting it to a pathogen, is possible but has not occurred in the field to an extent that has led to breakdown of biocontrol.

\section{Lessons to be learned from the crown gall-K84 story.}

Taken together, these details of K84 biology clearly indicate that this organism is not a random opportunistic soil microbe that happens to produce antibiotics that inhibit crown gall pathogens. Rather, it is the result of complex evolution and selection of traits to take advantage of the tumor environment induced by crown gall pathogens. Indeed, it was first isolated not in the absence of disease but associated with crown gall tumors. The very characteristics that make it effective for competing with pathogens in the crown gall disease niche make it such an effective biocontrol agent when introduced to uninfected plant propagation material before pathogen arrival in the infection court.

Baker and Cook (1972), in one of the classic texts in the area, Biological Control of Plant Pathogens (page 108), in discussing where to seek potential biocontrol agents, advise

\section{"Antagonists (i.e., control agents) should be sought in areas where the disease caused by a given pathogen does not occur, has declined, or cannot develop, despite the presence of a susceptible host, rather than where the disease occurs" (the bold type is Baker and Cook's).}

It is difficult to determine how much this advice has directed the progress (or lack thereof) in the field of biocontrol. It could very well be bad advice. It is certainly not supported by the crown gall biocontrol success story, in which strain K84 was isolated from a diseased plant niche that it has clearly evolved to exploit. My alternative advice is not to reject the diseased plant environment as a source of additional biocontrol agents that have evolved to cheat the pathogen.

Whether extensive analysis of the microbiomes associated with the infected plant can assist in the discovery of cheaters that can be converted into biocontrol agents of diverse plant diseases is yet to be demonstrated. Would microbiome analysis have identified strain $\mathrm{K} 84$ as an effective biocontrol agent? I think not. Nevertheless, the power of microbiomics will undoubtedly uncover much about the ecology of the disease plant niche. Questions that I find intriguing because of my own area of work are whether different microbiomes exist in uninfected wheat leaves and wheat leaves infected with Puccinia striiformis, the yellow rust pathogen of wheat, and does the disease-associated microbiome include microbial cuckoos and cheaters with potential biocontrol attributes (Hubbard et al. 2015)?

\section{LITERATURE CITED}

Baker, K. F., and Cook, R. J. 1974. Biological control of plant pathogens. WH Freeman and Company, San Francisco.

Bulgarelli, D., Schlaeppi, K., Spaepen, S., Ver Loren van Themaat, E., and Schulze-Lefert, P. 2013. Structure and functions of the bacterial microbiota of plants. Annu. Rev. Plant Biol. 64:807-838.

Donner, S. C., Jones, D. A., McClure, N. C., Rosewarne, G. M., Tate, M. E., Kerr, A., Fajardo, N. N., and Clare, B. G. 1993. Agrocin 434, a new plasmid encoded agrocin from the biocontrol Agrobacterium strains K84 and K1026, which inhibits biovar 2 agrobacteria. Physiol. Mol. Plant Pathol. 42:185-194.

El Sahili, A., Li, S. Z., Lang, J., Virus, C., Planamente, S., Ahmar, M., Guimaraes, B. G., Aumont-Nicaise, M., Vigouroux, A., Soulère, L., Reader, J., Queneau, Y., Faure, D., and Moréra, S. 2015. A pyranose-2-phosphate motif is responsible for both antibiotic import and quorum-sensing regulation in Agrobacterium tumefaciens. PLoS Pathog. 11:e1005071.

Ellis, J. G., Kerr, A., Petit, A., and Tempe, J. 1982. Conjugal transfer of nopaline and agropine Ti-plasmids-The role of agrocinopines. Mol. Gen. Genet. 186:269-274.

Ellis, J. G., Kerr, A., Van Montagu, M., and Schell, J. 1979. Agrobacterium: Genetic studies on agrocin 84 production and the biological control of crown gall. Physiol. Plant Pathol. 15:311-319.

Ellis, J. G., and Murphy, P. J. 1981. Four new opines from crown gall tumours-Their detection and properties. Mol. Gen. Genet. 181:36-43.

Goldmann, A., Thomas, D. W., and Morel, G. 1969. Sur la structure de la nopaline métabolite anormal de certaines tumeurs de crown-gall. CR Acad. Sci. Paris 268:852-854.

Grinter, R., Milner, J., and Walker, D. 2013. Beware of proteins bearing gifts: Protein antibiotics that use iron as a Trojan horse. FEMS Microbiol. Lett. 338:1-9.

Hayman, G. T., and Farrand, S. K. 1990. Agrobacterium plasmids encode structurally and functionally different loci for catabolism of agrocinopinetype opines. Mol. Gen. Genet. 223:465-473.

Hubbard, A., Lewis, C. M., Yoshida, K., Ramirez-Gonzalez, R. H., de Vallavieille-Pope, C., Thomas, J., Kamoun, S., Bayles, R., Uauy, C., and Saunders, D. G. 2015. Field pathogenomics reveals the emergence of a diverse wheat yellow rust population. Genome Biol. 16:23. 
Jones, D. A., and Kerr, A. 1989. Agrobacterium radiobacter strain K1026, a genetically engineered derivative of strain K84, for biological control of crown gall. Plant Dis. 73:15-18.

Jones, D. A., Ryder, M. H., Clare, B. G., Farrand, S. K., and Kerr, A. 1988. Construction of a Tra ${ }^{-}$deletion mutant of pAgK84 to safeguard the biological control of crown gall. Mol. Gen. Genet. 212:207-214.

Kerr, A., and Htay, K. 1974. Biological control of crown gall through bacteriocin production. Physiol. Plant Pathol. 4:41-44.

Kerr, A., and Roberts, W. P. 1976. Agrobacterium: Correlations between and transfer of pathogenicity, octopine and nopaline metabolism and bacteriocin 84 sensitivity. Physiol. Plant Pathol. 9:205-211.

Kerr, A. 2016. Biological control of crown gall. Australasian Plant Pathol. 45:15-18.

Kim, H., and Farrand, S. K. 1997. Characterization of the acc operon from the nopaline-type Ti plasmid pTiC58, which encodes utilization of agrocinopines A and B and susceptibility to agrocin 84. J. Bacteriol. 179:7559-7572.

Kim, J. G., Park, B. K., Kim, S. U., Choi, D., Nahm, B. H., Moon, J. S., Reader, J. S., Farrand, S. K., and Hwang, I. 2006. Bases of biocontrol: Sequence predicts synthesis and mode of action of agrocin 84 , the Trojan horse antibiotic that controls crown gall. Proc. Natl. Acad. Sci. U.S.A. 103:8846-8851.

McClure, N. C., Ahmadi, A. R., and Clare, B. G. 1998. Construction of a range of derivatives of the biological control strain agrobacterium rhizogenes K84: A study of factors involved in biological control of crown gall disease. Appl. Environ. Microbiol. 64:3977-3982.

New, P. B., and Kerr, A. 1971. A selective medium for Agrobacterium radiobacter biotype 2. J. Appl. Bacteriol. 34:233-236.

New, P. B., and Kerr, A. 1972. Biological control of crown gall: Field measurements and glasshouse experiments. J. Appl. Bacteriol. 35: 279-287.

Panagopoulos, C., Psallidas, P., and Alivizatos, A. 1978. Evidence of a breakdown in the effectiveness of biological control of crown gall. Pages 569-578 in: Soil-Borne Pathogens. B. Schippers and W. Gams, eds. Academic Press, New York.
Penyalver, R., Oger, P., López, M. M., and Farrand, S. K. 2001. Ironbinding compounds from Agrobacterium spp.: Biological control strain Agrobacterium rhizogenes K84 produces a hydroxamate siderophore. Appl. Environ. Microbiol. 67:654-664.

Poudel, R., Jumpponen, A., Schlatter, D. C., Paulitz, T. C., Gardener, B. B., Kinkel, L. L., and Garrett, K. A. 2016. Microbiome networks: A systems framework for identifying candidate microbial assemblages for disease management. Phytopathology 106:1083-1096.

Raaijmakers, J. M., and Mazzola, M. 2016. Soil immune responses. Science 352:1392-1393.

Reader, J. S., Ordoukhanian, P. T., Kim, J. G., de Crécy-Lagard, V., Hwang, I., Farrand, S., and Schimmel, P. 2005. Major biocontrol of plant tumors targets tRNA synthetase. Science 309:1533.

Rebuffat, S. 2012. Microcins in action: Amazing defence strategies of Enterobacteria. Biochem. Soc. Trans. 40:1456-1462.

Rose, M. R. 1978. Cheating in evolutionary games. J. Theor. Biol. 75: 21-34.

Ryder, M. H., Slota, J. E., Scarim, A., and Farrand, S. K. 1987. Genetic analysis of agrocin 84 production and immunity in Agrobacterium spp. J. Bacteriol. 169:4184-4189.

Ryder, M. H., Tate, M. E., and Jones, G. P. 1984. Agrocinopine A, a tumorinducing plasmid-coded enzyme product, is a phosphodiester of sucrose and L-arabinose. J. Biol. Chem. 259:9704-9710.

Servick, K. 2016. Earth's microbes get their own White House initiative. Science 352:1506.

Tate, M. E., Murphy, P. J., Roberts, W. P., and Keer, A. 1979. Adenine N6 substituent of agrocin 84 determines its bacteriocin-like specificity. Nature 280:697-699.

Young, J. M., Kuykendall, L. D., Martínez-Romero, E., Kerr, A., and Sawada, H. 2001. A revision of Rhizobium Frank 1889, with an emended description of the genus, and the inclusion of all species of Agrobacterium Conn 1942 and Allorhizobium undicola de Lajudie et al. 1998 as new combinations: Rhizobium radiobacter, $R$. rhizogenes, $R$. rubi, $R$. undicola and $R$. vitis. Int. J. Syst. Evol. Microbiol. 51:89-103. 